Our Nature (2008)6:19-25

\title{
Role of Avian Community in Reduction of Spodoptera Pest Population in Sugar Beet at Pune
}

\author{
S.B. Shivankar ${ }^{1}$, S.B. Magar, V.D. Shinde, P.V. Ghodake, R.G. Yadav and A.S. Patil \\ Vasantdada Sugar Institute, Manjari (Bk.), Pune- 412 307, India \\ ${ }^{1}$ Email: shivankar.santosh@rediffmail.com
}

Received: 12.07.2008, Accepted: 08. 10.2008

\begin{abstract}
Experiments were conducted at Vasantdada Sugar Institute, Pune in a RBD with three replications during 2005 to 2007 in sugar beet (var. posada) for control of Spodoptera litura Fab.

The ornithological studies had shown the major avian community, Acridotheres tristis (Linnaeus), Passer domesticus (Linnaeus), Vanellus indicus (Boddaert), Corvus splendens (Vieillot), Centropus sinensis (Stephens), Pycnonotus cafer (Linnaeus), Eudynamys scolopacea (Linnaeus), with a relative abundance of 14.33, 13.26, 11.46, 5.73, 3.87, 3.54, and $2.79 \%$, respectively.

The reduction in mean $S$. litura population due to the pick up of the larvae by birds during three crop seasons ranged from 33.90 to $69.47 \%$. Installation of minimum 15 bird perches/ha in 60 days after sugar beet sowing noticed effective considering the number of birds sittings (130.66/day), reduction in larval population of S. litura $(39.99 \%)$, and root yield (71.36 ton/ha).
\end{abstract}

Keywords: Sugar beet, Spodoptera, avian community, yield.

\section{Introduction}

Beta vulgaris Linnaeus is the second largest crop after sugar cane for sugar production in the world and about $28 \%$ sugar is produced from sugar beet. Sugar beet contains 3 to $4 \%$ more sucrose than sugar cane (Baloach et al., 2002). Being a new crop in India, several constraints are noticed in cultivation of sugar beet and severe incidence of pests and diseases is a major (Patil et al., 2007).

Defoliating pests viz. Spodoptera litura Fab., Diacrisia obliqua Walker, Plusia orichalcea Fab. and Agrotis ypsilon Rott. have cause the appreciable damage to Tropical sugar beet (Avasthy and Srivastava, 1972; Khan and Sharma, 1971; Singh et al., 1980; Tewari et al., 1986; Patil et al., 2007). Cent per cent defoliation has resulted, $42 \%$ beet root yield loss (Muro and Irigoyen, 1998).
Beet armyworm was a major pest causing severe damage. Young larvae skeletonise the leaves however; the older ones eat the entire lamina and defoliate the crop completely in a very short period (Cooke, 1993 and Patil et al., 2007). The full grown larvae of $S$. litura also feed on beet roots, as they live in the soil during the day time. Development of ecofriendly management practices to obtain the sustained crop yields over a long period is highly essential.

Passer domesticus (Linnaeus) is recorded by Gopi et al. (2001) as an avian natural enemy of Aleurodicus disperses Russell. Dead sewer rat, offal, carrion, kitchen scraps and refuse, locusts, termites, fruits, grains and eggs or fledgling birds as 
the food of Corvus splendens (Vieillot) were described by Ali (1989) and Thirumurthy and Annamalai (1994). House crow was noticed to feed on crabs (a destructive pest of paddy), rodents, mice and cattle egret, common myna, red-vented bulbul ate the grasshoppers (Regmi, 2003).

Installation of 8-10 bird perches/hectare in cotton was recommended after 90 days of crop growth for the benefit of predatory birds like black drango, king crow, orange myna and blue jay in cotton were recommended after 90 days of crop growth (Anonymous, 2004).

Considering the pollution, problems of chemical insecticides, related to soil, water, natural enemies of pests, resistance, and residue etc., the present work will help to minimize the pest problem in a cheaper and safe way.

\section{Materials and methods}

Experiments were conducted at VSI, Pune (Latitude $18^{0} 32^{\prime} \mathrm{N}, \quad$ Longitude $73^{0} 51^{\prime} \mathrm{E}$, Altitude $559 \mathrm{~m}$, Temp. $15^{0}$ to $45^{\circ} \mathrm{C}$ ) in a RBD with three replications during winter (2005-06 and 2006-07) and summer season (2006). Sugar beet (var. posada) was sown on 30.11.2005, 07.12.2006, and 03.06.2006, respectively. Row to row and plant to plant distance was 50 and $20 \mathrm{~cm}$, respectively with a plot size of $5 \times 4 \mathrm{~m}^{2}$ and recommended agronomical practices were followed.

' $\mathrm{T}$ ' shaped wooden bird perches @ 5, 10, 15,20 and 25 no./ha were installed at 60 days after sowing and effect checked against uninstalled plot, in three seasons. During morning and evening hours, the number of bird species and number of bird sittings were recorded every day for 15 days, in each season as per group of the bird perches. Relative abundance (\%) was worked out. Major bird species were identified based on physical features with the help of field guides and reference books (Ali and Ripley, 1983).

Randomly five plants were selected in each plot and live larvae of $S$. litura were counted in each plant before and after the installation of bird perch.

Ten randomly selected beet roots were harvested and weighed from each treatment at a crop age of 5.50 months, juice pol and purity (\%) were analyzed by Cold Method (Le Docte, 1927).

\section{Results and discussion}

The ornithological studies taken during 2005 to 2007, in sugar beet at Pune indicated that seven major species viz. Acridotheres tristis (Linnaeus), $P$. domesticus, Vanellus indicus (Boddaert), C. splendens, Centropus sinensis (Stephens), Pycnonotus cafer (Linnaeus), Eudynamys scolopacea (Linnaeus), from six families and others had shown their presence (Table 1). The Cattle Egret Bubulcus ibis (Linnaeus), family Ardeidae was also noticed during the inter culturing operations. Abdulali (1973) has reported existence of 525 species of birds in Maharashtra State.

The relative abundance (Table 2) of avian community indicated the dominance $(58.55 \%)$ of common myna during winter 2005-06, Asian Koel (34.04\%) in summer, 2006 and House crow $(52.31 \%)$ in winter, 2006-07. The variation in abundance may be due to coverage of other crops around the beet fields, feeding preference of pests, etc. However, in general, among the major bird species, common myna has a maximum $(14.33 \%)$ abundance followed by house sparrow (13.26), red wattled lapwing (11.46), house crow (5.73), greater coucal (3.87), red-vented bulbul (3.54) and Asian 
Table 1. Birds recorded in sugar beet fields at Pune (India).

\begin{tabular}{|l|c|c|}
\hline Common name & Scientific name & Family \\
\hline House Sparrow & P. domesticus & Passeridae \\
\hline House Crow & C. splendens & Corvidae \\
\hline Common Myna & A. tristis & Sturnidae \\
\hline Asian Koel & E. scolopacea & Cuculidae \\
\hline Greator Coucal & C. sinensis & Cuculidae \\
\hline Red - Vented Bulbul & P. cafer & Pycnonotidae \\
\hline Red Wattled Lapwing & V. indicus & Charadriidae \\
\hline
\end{tabular}

Season I - Winter (2005-06); II - Summer (2006); III - Winter (2006-07)

Table 2. Relative abundance of birds in various seasons in sugar beet fields.

\begin{tabular}{|c|c|c|c|c|}
\hline \multirow[t]{2}{*}{ Common name } & \multicolumn{4}{|c|}{$\%$ relative abundance } \\
\hline & Season I & Season II & Season III & Average \\
\hline House sparrow & 57.06 & 15.30 & 27.64 & 13.26 \\
\hline $\begin{array}{l}\text { House } \\
\text { Crow }\end{array}$ & 17.95 & 29.74 & 52.31 & 5.73 \\
\hline Common Myna & 58.55 & 9.99 & 31.46 & 14.33 \\
\hline $\begin{array}{l}\text { Asian } \\
\text { Koel }\end{array}$ & 28.07 & 34.04 & 37.89 & 2.79 \\
\hline Greator Coucal & 29.62 & 31.65 & 38.73 & 3.87 \\
\hline Red-vented Bulbul & 33.80 & 31.58 & 34.63 & 3.54 \\
\hline Red Wattled Lapwing & 46.36 & 17.11 & 36.53 & 11.46 \\
\hline Other & 80.50 & 8.34 & 11.16 & 45.03 \\
\hline
\end{tabular}

Season I - Winter (2005-06); II - Summer (2006); III - Winter (2006-07)

koel $(2.79 \%)$. The other birds had also shown the relative abundance of $45.03 \%$ but it varies due to various environmental factors, food availability, competition, presence of other crops in the area etc. The common crow, myna and sparrow noticed to feed on various stages of white grubs exposed during ploughing (Bhaketia et al., 1984), while common crow and sparrow were recorded as a natural enemies on armyworm (Bindra and Singh, 1973).

House sparrow reported to graze on crops. Rooks were also noticed to kill the sugar beet plant by uprooting them whilst searching for wireworm and other soil invertebrates (Dewar and Cooke, 2006) and, therefore, it is possible to cause the damage by some of the birds during early stage of sugar beet. Therefore, it is suggested that bird perches need to be erected when the appropriate foliage canopy of sugar beet develops. It seems that there is no need to use bird perches for control of S. litura during the early growth of sugar beet.

The role of bird perch on number of bird sittings in S. litura affected sugar beet field in three seasons with a $5,10,15,20$, and 25 bird perches per hectare were studied. It was observed that common myna preferred maximum of 11.41 sittings/perch in winter season of 2005-06 in a 15 days period followed by a house sparrow with 10.29 sittings and red wattled lapwing with 7.23 sittings and the remaining preferred from 1.07 to 6.13 sittings (Table. 3 ) for picking of live larvae. It was also noticed that these seven species of birds visited the fields during morning and evening hours however, they preferred to visit mostly during the morning hours.

Increase in number of bird perches had increased the more sittings of the birds. 
S.B. Shivankar, S.B. Magar, V.D. Shinde, P.V. Ghodake, R.G. Yadav and A.S. Patil/ Our Nature (2008) 6: 19-25

Table 3. Average bird sittings on perch in sugar beet fields.

\begin{tabular}{|c|c|c|c|c|c|c|c|c|}
\hline \multirow{3}{*}{$\begin{array}{c}\text { Common } \\
\text { name }\end{array}$} & \multirow{3}{*}{ Season } & \multicolumn{6}{|c|}{ No. of birds recorded on bird perches } & \multirow{3}{*}{$\begin{array}{l}\text { Avg. bird } \\
\text { sittings/ } \\
\text { perch }\end{array}$} \\
\hline & & \multicolumn{6}{|c|}{ No of bird perch / ha. } & \\
\hline & & 5 & 10 & 15 & 20 & 25 & Total & \\
\hline \multirow{3}{*}{$\begin{array}{l}\text { House } \\
\text { Sparrow }\end{array}$} & I & 75 & 150 & 135 & 202 & 210 & 772 & 10.29 \\
\hline & II & 15 & 50 & 35 & 39 & 68 & 207 & 2.76 \\
\hline & III & 46 & 53 & 89 & 65 & 121 & 374 & 4.99 \\
\hline \multirow{3}{*}{$\begin{array}{l}\text { House } \\
\text { Crow }\end{array}$} & $\mathrm{I}$ & 15 & 29 & 31 & 16 & 14 & 105 & 1.40 \\
\hline & II & 13 & 21 & 33 & 39 & 68 & 174 & 2.32 \\
\hline & III & 54 & 49 & 55 & 66 & 82 & 306 & 4.08 \\
\hline \multirow{3}{*}{$\begin{array}{l}\text { Common } \\
\text { Myna }\end{array}$} & $\mathrm{I}$ & 89 & 142 & 147 & 245 & 233 & 856 & 11.41 \\
\hline & II & 29 & 22 & 37 & 25 & 33 & 146 & 1.95 \\
\hline & III & 94 & 76 & 91 & 84 & 115 & 460 & 6.13 \\
\hline \multirow{3}{*}{$\begin{array}{l}\text { Asian } \\
\text { Koel }\end{array}$} & I & 7 & 12 & 31 & 16 & 14 & 80 & 1.07 \\
\hline & II & 9 & 20 & 29 & 21 & 18 & 97 & 1.29 \\
\hline & III & 12 & 24 & 28 & 31 & 13 & 108 & 1.44 \\
\hline \multirow{3}{*}{$\begin{array}{l}\text { Greator } \\
\text { Coucal }\end{array}$} & I & 8 & 12 & 17 & 39 & 41 & 117 & 1.56 \\
\hline & II & 13 & 15 & 20 & 34 & 43 & 125 & 1.67 \\
\hline & III & 5 & 21 & 46 & 25 & 56 & 153 & 2.04 \\
\hline \multirow{3}{*}{$\begin{array}{l}\text { Red - Vented } \\
\text { Bulbul }\end{array}$} & I & 21 & 19 & 25 & 24 & 33 & 122 & 1.63 \\
\hline & II & 16 & 16 & 22 & 29 & 31 & 114 & 1.52 \\
\hline & III & 6 & 21 & 23 & 34 & 41 & 125 & 1.67 \\
\hline \multirow{3}{*}{$\begin{array}{l}\text { Red Wattled } \\
\text { Lapwing }\end{array}$} & I & 102 & 87 & 99 & 146 & 108 & 542 & 7.23 \\
\hline & II & 60 & 47 & 29 & 36 & 28 & 200 & 2.67 \\
\hline & III & 65 & 64 & 87 & 99 & 112 & 427 & 5.69 \\
\hline \multirow{4}{*}{ Other } & I & 482 & 646 & 670 & 925 & 976 & 3699 & 49.32 \\
\hline & II & 68 & 82 & 85 & 76 & 72 & 383 & 5.11 \\
\hline & III & 45 & 79 & 96 & 145 & 148 & 513 & 6.84 \\
\hline & Total & 1349 & 1757 & 1960 & 2461 & 2678 & 10205 & \\
\hline
\end{tabular}

Season I - Winter (2005-06); II - Summer (2006); III - Winter (2006-07)

Placement of 25 perches/ha had shown the maximum of 2678 sittings/ha, while in 5 perches/ha, it was 1349 sittings.

In all the seasons, the mean larval population of $S$. litura ranged from 5.48 to 7.72/plant before the placement of bird perches and it was sufficient to cause the economic damage to sugar beet crop (Table 4). The maximum 14.80 larvae/plant were noticed in a check plot. The mean population of larvae during I, II, and III seasons ranged from 2.05 to $6.93,2.87$ to 8.40 , and 2.87 to $4.27 /$ plant, respectively and in control it was 6.80 to $12.11 /$ plant. Therefore, the reduction in larval population due to placement of bird perches in I, II, and III crop seasons ranged from 42.17 to 83.07 , 21.71 to 73.25 , and 37.21 to $57.79 \%$, respectively. The mean larval population reduction of three seasons ranged from 33.90 to $69.47 \%$. 
S.B. Shivankar, S.B. Magar, V.D. Shinde, P.V. Ghodake, R.G. Yadav and A.S. Patil/ Our Nature (2008) 6: 19-25
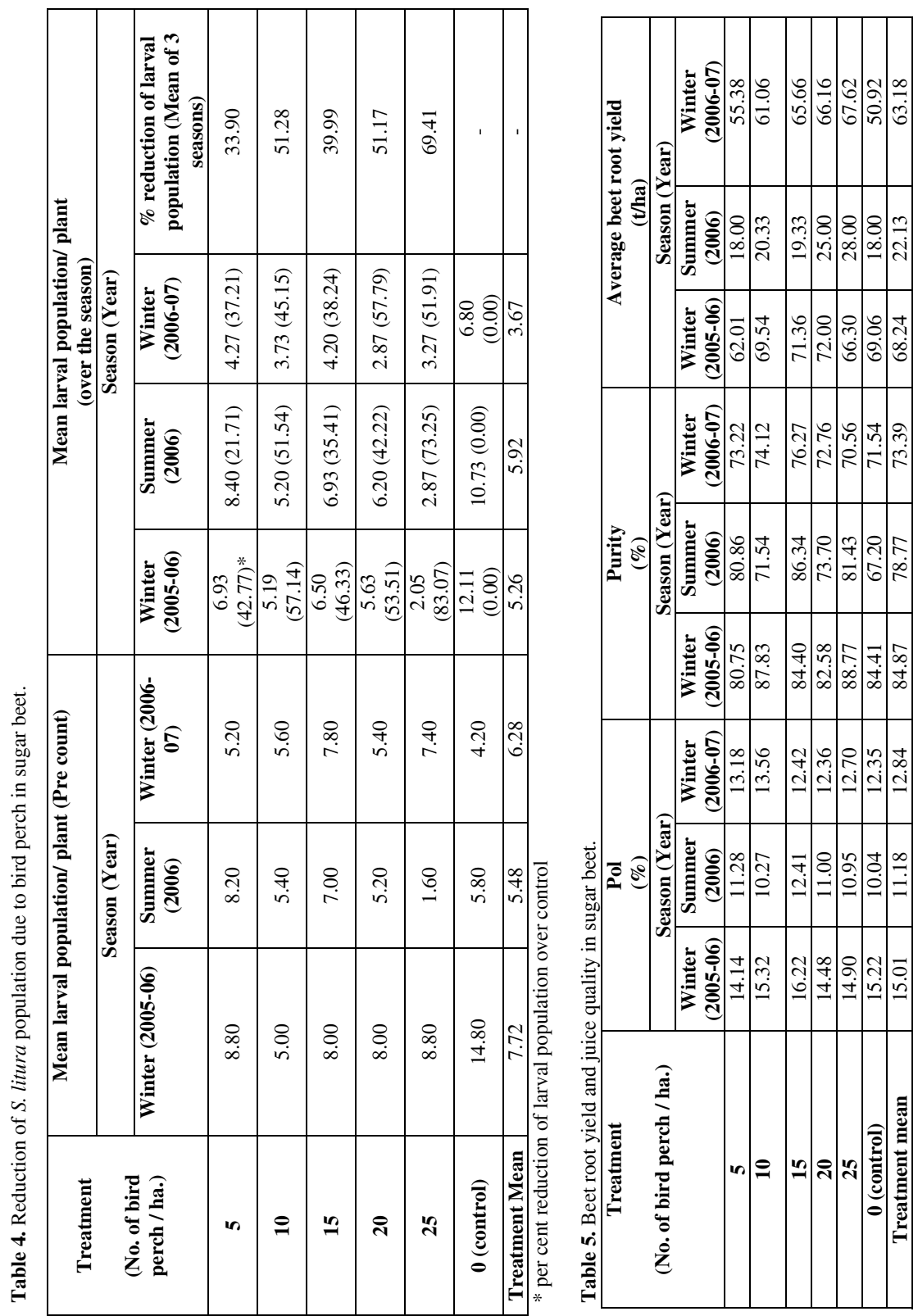
At harvest, the maximum pol, purity, and beet root yield was recorded in winter crop (2005-06) and it was $16.22 \%, 88.77 \%$, and 72.00 ton/ha, respectively while in control it was $15.22 \%, 84.45 \%$, and 69.06 ton/ha, respectively (Table 5). The summer (2006) crop gave poor beet root yield mainly due to the stagnation of water, which result severe rotting of beet roots. In general, it is concluded that installation of 15 bird perches/ha at 60 days after sowing noticed feasible considering the no. of birds sittings, reduction in larval population of $S$. litura, beet root yield and juice quality, as there is no much differences in placement of 20 and 25 bird perches/ ha.

\section{Acknowledgements}

We are grateful to the Indian Council of Agricultural Research (ICAR), New Delhi, India for necessary funding for research work in sugar beet through network project. We are thankful to the Director General, Vasantdada Sugar Institute, Pune for providing the necessary facilities. The heartiest thanks to the management of Syngenta India Ltd.; Seeds Division, Pune; and Director, Indian Institute of Sugarcane Research, Lucknow for the supply of sugar beet seed.

\section{References}

Abdulali, H. 1973. Check list of birds of Maharashtra Bombay Natural History Society, Bombay. pp. 1-16.

Ali, S. 1989. The birds of Sikkim. Oxford University Press. 414 p.

Ali, S. and S.D. Ripley 1983. Hand Book of the Birds of India and Pakistan. Oxford University Press, Oxford. 737 p.

Anonymous, 2004. Integrated pest management practice for cotton. IPM package No. 25, Ministry of Agriculture,
Dept. of Agriculture and Co- operation, Directorate of plant protection, Quarantine and storage, Govt of India, 2003-04. 6 p.

Avasthy, P.N. and T.N. Srivastava 1972. Pest problem in sugar beet cultivation. Indian Farmers Digest 10(5): 27-29.

Baloach, M.S., I.H. Shah, I. Hussain and K. Abdullah 2002. Low Sugar Production in Pakistan: Causes and remedies. Pak. Sugar J. 17(5): 13-15.

Bhaketia, D.R.C., K.S. Brar and R.S. Gill 1984. Mortality factors in the natural population of Holotrichia consanguinea Blanch. (Col. Scarabeidae). J. Soil Biol. Ecol. Pp. 62-64.

Bindra, O.S. and J. Singh 1973. Bionomics of armyworm, Mythimna separata (Wlk.) (Lepidoptera: Noctuidae) at Ludhiana, Punjab. Indian J. Agric. Sci. 43: 299-303.

Cooke, D.A. 1993. Pests. In The Sugar beet Crop (Eds. D.A. Cooke and R.K. Scott). Chapman and Hall publ. pp. 428-465.

Dewar, Alan M. and David A. Cooke 2006. Pests. Sugar Beet. (Eds. Philip A. Draycott). pp. 316-350.

Gopi, D., T.N. Neelanavar and S. Thirumurthi 2001. Incidence of spiraling whitefly, Aleurodicus disperses Russell among tree species. Abstracts. National seminar on emerging trends on pests and diseases and their management, T.N.A.U., Coimbatore, India, 11-13 Oct.-2001. pp. 71-72.

Khan, R.M. and S.K. Sharma 1971. Some new pest record on sugar beet in India. Indian J. Ento. 33(1): 105-106.

Le Docte, A. 1927. Commercial determination of sugar in the beet root using the sochs-le Docte process. Int. Sug. J. 29: 488-492. 
S.B. Shivankar, S.B. Magar, V.D. Shinde, P.V. Ghodake, R.G. Yadav and A.S. Patil/ Our Nature (2008) 6: 19-25

Muro Julio and Irigoyen Ignacio 1998. Defoliation timing and severity in sugar beet. Agronomy Journal. 90: 800-804.

Patil A.S., A.N. Salunkhe, B.H. Pawar, P.V. Ghodke, S.B. Shivankar, N.B. Zende, S.R. Shewate and D.J. Patil 2007. Sugar beet Cultivation in Tropical India-A New Experience. Proc. $68^{\text {th }}$ Annual Conv., STAI, New Delhi, 22 ${ }^{\text {nd }}-24^{\text {th }}$ August, 2007, pp. 85-111.

Regmi, N. 2003. Role of birds in agricultural pest control. Our Nature I(1): 68-70.
Singh K.N., G.C. Sachan and R.C. Chhibber 1980. Effects of some insecticides on sugar beet defoliation by lepidopterous larvae. Indian Sugar. pp. 157-160.

Tewari, R.K., A.K. Mehrotra, P.K. Bajpai and P.N. Avasthy 1986. Assessment of losses caused by defoliating pests to sugar beet crop (Beta vulgaris Linn.). Co-operative sugar, 17(12): 943-945.

Thirumurthy, S. and R. Annamalai 1994. Birds as pest controllers and depredators. Newsletter for bird watcher 34(2). 